\title{
Simulation of hydrodesulfurization unit for natural gas condensate with high sulfur content
}

\author{
Javad Alaei Kadijani ${ }^{1} \cdot$ Elhameh Narimani $^{2}$
}

Received: 8 January 2015 / Accepted: 2 April 2015/Published online: 29 April 2015

(c) The Author(s) 2015. This article is published with open access at Springerlink.com

\begin{abstract}
The natural gas condensates are composed of various components of hydrocarbons and some contaminants such as hydrogen sulfide, thiols (mercaptans), and aromatics. Thus, the natural gas condensates could be considered as a fuel resource. This study concerned the simulation of an Ultra-Deep Hydrodesulfurization (UDHDS) unit plus a distillation section to treat a combination of gas condensate and disulfide oils (DSO) and produce clean fuel cuts. Gas condensate of South Pars field of Iran with high sulfur content was applied to obtain clean fuel cuts. In order to reduce the sulfur content of this stream to less than 10 ppmw as sulfur, a UDHDS unit was simulated using Aspen HYSYS software package. The clean gas condensate leaving the UDHDS unit (with sulfur content $<10 \mathrm{ppmw}$ ) contains complex mixtures of hydrocarbon components called petroleum cuts which are identified by their boiling points ranges. To obtain the narrow fractions of butane, light naphtha, heavy naphtha, kerosene, and gasoil, a fractional distillation system was simulated. The simulation results revealed that the top products of distillation column, namely butane, light naphtha, and heavy naphtha were sulfur free and the sulfur contents of kerosene and gasoil cuts were 12 and $27 \mathrm{ppmw}$ as sulfur, respectively.
\end{abstract}

Elhameh Narimani

inspirationj82@gmail.com

Javad Alaei Kadijani

JAVAD.ALAEI@RIPI.IR

1 Research Institute of Petroleum Industry (RIPI), Gas Department, West Boulevard of Azadi Stadium,

P. O. Box 14665-1998, Tehran, Iran

2 School of Chemical Engineering, Iran University of Science and Technology, P.O. Box 16765-163, Tehran, Iran
Keywords Gas condensates - Disulfide oils - Sulfur content · Ultra-Deep Hydrodesulfurization unit · Petroleum cuts · Fractional distillation system

$\begin{array}{ll}\text { Abbreviations } \\ \text { ANN } & \text { Artificial neural network } \\ \text { DEAmine } & \text { Diethyl amine } \\ \text { DEDS } & \text { Diethyl disulfide } \\ \text { DMDS } & \text { Dimethyl disulfide } \\ \text { DSO } & \text { Disulfide oil } \\ \text { F.B.P. } & \text { Final boiling point } \\ \text { FLR } & \text { Flare } \\ \text { HDA } & \text { Hydrodearomatization } \\ \text { HDN } & \text { Hydrodenitrogenation } \\ \text { HDS } & \text { Hydrodesulfurization } \\ \text { IEA } & \text { International energy agency } \\ \text { I.B.P. } & \text { Initial boiling point } \\ \text { OSBL } & \text { Outside battery limit } \\ \text { Nm } & \text { Cubic meters @ normal condition }\left(0^{\circ} \mathrm{C}\right) \\ \text { PFD } & \text { Process flow diagram } \\ \text { ppmw } & \text { Parts per million weight } \\ \text { RSM } & \text { Response surface methodology } \\ \text { TBP } & \text { True boiling point } \\ \text { UDHDS } & \text { Ultra-Deep Hydrodesulfurization } \\ \text { VGO } & \text { Vacuum gasoil }\end{array}$

\section{Introduction}

Looking at the world's growing demand for new energy resources, experts in the field of oil and energy can obviously realize that oil industry has to find new fuel supplies and upgrade their qualities. The natural gas condensates can

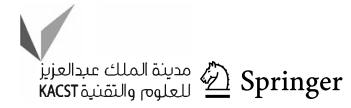


catch their attention as they contain complex mixtures of hydrocarbon components. Natural gas condensate is known as a low-boiling mixture of hydrocarbon liquids that are present as gaseous components in the raw natural gas produced from many natural gas fields [1]. Therefore, in addition to crude oil, the natural gas condensate can be an appropriate resource for oil industry to augment the fuel production. According to the report of International Energy Agency (IEA), the South Pars/North Dome field, which is located in the Persian Gulf, is the world's largest gas field and shared between Iran and Qatar. This field holds an estimated 1800 trillion cubic feet (51 trillion cubic meters) of in situ natural gas and some 50 billion barrels ( 7.9 billion cubic meters) of natural gas condensates. ${ }^{1}$ However, the gas condensate of this field is substantially sour as it is estimated that the sulfur content of gas condensate of South Pars field is more than 2000 ppmw as sulfur. The sulfur content of fuels is currently considered as a major factor contributing to pollution of the atmosphere.

Accordingly, the U.S. Environmental Protection Agency limited the sulfur content of most diesel fuels to $15 \mathrm{ppm}$ from a level of $500 \mathrm{ppm}$ in 2006. The similar environmental regulations in Europe forced petroleum industries to reduce the sulfur content for on-road diesel fuels from the level of $350-50$ ppm by 2005 and to 10 ppm by 2009 . Furthermore, based on the Euro V criterion, the bound for fuels, in terms of total sulfur content has to be less than $10 \mathrm{ppm}$ as sulfur. The sulfuric compounds in fossil fuels are divided into nonaromatic and aromatic compounds. The first group includes sulfides, disulfides, and mercaptans (thiols) and the second one includes thiophenes, benzothiophenes, dibenzothiophenes, and benzonaphthothiophenes. The former has much more reactivity than the other sulfuric compounds while the latter, particularly benzothiophenic and dibenzothiphenic derivatives, are difficult to desulfurize.

Hydrodesulfurization (HDS) is known as one of the most efficient methods to reduce the sulfur content of hydrocarbons regarding universal criteria. This process can be extremely effective in removing both types of sulfuric compounds. In this plant, the reaction takes place under high temperature and high hydrogen pressure in the presence of a catalyst. HDS process can accomplish desulphurization and in the meanwhile it can remove nitrogen and metal compounds, and also carry out deoxidation.

Based on the advantages of hydrodesulfurization process-removing less than $10 \mathrm{ppm}$ sulfur, decreasing the amount of environmental pollutants, increasing the age of catalysts, simple operation of process unit to name but a few-it is considered as an appropriate method to reduce the sulfur content of gas condensate [2-7]. There are some

\footnotetext{
${ }^{1}$ Data are extracted from APS Review Gas Market Trends. April 2, 2007.

studies investigating the simulation and modeling of HDS plants. The research conducted by S. Bilal et al. [8] focused on the simulation of an HDS unit using Aspen HYSYS with the aim of removing impurities such as sulfur and nitrogen from raw kerosene. F. Jiménez et al. [9] carried out computer-aided modeling as a tool for the investigation of simultaneous Hydrodesulfurization (HDS), Hydrodenitrogenation (HDN), and Hydrodearomatization (HDA) of a vacuum gasoil (VGO) in which reactions took place in industrial reactors. Another study explored the use of different artificial neural network (ANN) architectures in creating various models of the HDS process for the prediction of sulfur removal from naphtha [10]. Ultra-Deep Hydrodesulfurization (UDHDS) process is considered as one of the subbranches of the conventional HDS process which is conducted in the severe process conditions and using different catalyst to obtain the lower amount of sulfur content.

In addition to the HDS unit, a distillation system is required to obtain clean cuts. However, the order of these two sections is a problem. Based on a technical recommendation study report given by HQCEC, the hydrogenation plus fractionation process to treat naphtha can produce clean product with high quality and low impurity content compared with the fractionation plus hydrogenation units. Moreover, the energy consumption of these two plants was approximately equal. In terms of investment, the system capacity of hydrogenation plus fractionation process is slightly higher than that of the fractionation plus hydrogenation processes [11]. However, in these studies, costs and problems caused by sour petroleum cuts have been ignored. Gas condensate of South Pars field is currently sent to refineries to produce fuel cuts or sold in markets. In both cases, gas condensate with high sulfur content or sour petroleum cuts can seriously damage pipelines and process equipment due to corrosion and push up the cost of process. In the present study, it has been assumed that the primary design of sulfur removal unit for gas condensate should be based on the UDHDS plant plus a fractional distillation unit.

Regarding the world's increasing need for clean fuels as well as environmental issues resulting from high-sulfur fuel burning, it was assumed that a new UDHDS unit treating the natural gas condensate of South Pars field and producing the ultra-low sulfur fuel cuts from them would attract investments and get back more interests in the universal markets. Moreover, this process can protect downstream equipment from corrosion and cut down costs of maintenance. Furthermore, there is an environmental issue which is related to the production of disulfide oil. The substance, commonly known as disulfide oil (DSO), can comprise 17 different disulfides and trisulfides with monoalkyl chain lengths no greater than $\mathrm{C} 4$. Evidence demonstrates that the lowest series member, dimethyl disulfide (DMDS), can display the highest toxicity. DSO possesses high aquatic toxicity, 
moderate environmental persistence, high repeated dose toxicity, carcinogenicity, and reproductive/developmental effects [12].

DSOs (mainly dimethyl and diethyl disulfides) are formed in considerable amounts in the process of hydrocarbon demercaptanization in refineries. Presently, there is no practical application for DSO. Furthermore, destruction of DSO by combustion would lead to the formation of sulfur dioxide and carbonyl compounds which can pollute the atmosphere. Fortunately, DSOs are highly active in the catalytic reaction with hydrogen and they can be easily removed and converted to alkanes and hydrogen sulfide in the hydrodesulfurization process.

Therefore, the aim of this study is the simulation of a new UDHDS unit plus a distillation section in South Pars refinery which would treat the natural gas condensate with high sulfur content and produce clean and sellable fuel cuts. Moreover, regarding aforementioned problems caused by DSOs in this refinery, in this simulation a stream of DSOs was added to gas condensate which was sent to UDHDS unit as a feed. The simulated UDHDS unit plus distillation section would treat gas condensate and totally remove DSOs from this refinery. The results of the present work can be used to build a new UDHDS unit to treat the gas condensate of South Pars field and produce clean fuel cuts. The main difference between this UDHDS process and conventional UDHDS processes is related to the feed of this simulated unit which is a combination of gas condensate and DSO while the feed of the conventional UDHDS units is usually petroleum cuts like naphtha, gasoil, or kerosene. In this simulation, it was assumed that the total sulfur content of gas condensate after treatment should reach less than 10 ppmw as sulfur.

At the end, a distillation column was joined to the simulation in order to obtain the clean cuts of butane, light and heavy naphtha, kerosene, and Gasoil from treated gas condensate.

\section{Methods and materials}

The specification of gas condensate based on TBP (True Boiling Point) used in this study is shown in Table 1. In addition, Fig. 1 shows the boiling point curve of gas condensate. Tables 2 and 3 indicate the non-sulfuric and sulfuric components of gas condensate.

The feed of UDHDS unit was the gas condensate flow combined with a stream of DSO. It should be taken into consideration that at the ambient conditions (temperature $27{ }^{\circ} \mathrm{C}$ and atmospheric pressure) DSO is totally dissolvable in gas condensate. The boiling points and mass contents of two sulfuric compounds of the DSO used in this study are shown in Table 4.
Table 1 The specification of gas condensate based on TBP

\begin{tabular}{ll}
\hline Volume, $\%$ & TBP $\left({ }^{\circ} \mathrm{C}\right) @ 760 \mathrm{mmHg}$ \\
\hline 5.18 & 15 \\
11.49 & 36.1 \\
53.24 & 150 \\
63.09 & 175 \\
73.41 & 215 \\
81.76 & 250 \\
87.01 & 275 \\
95.81 & 350 \\
100 & 360 \\
\hline
\end{tabular}

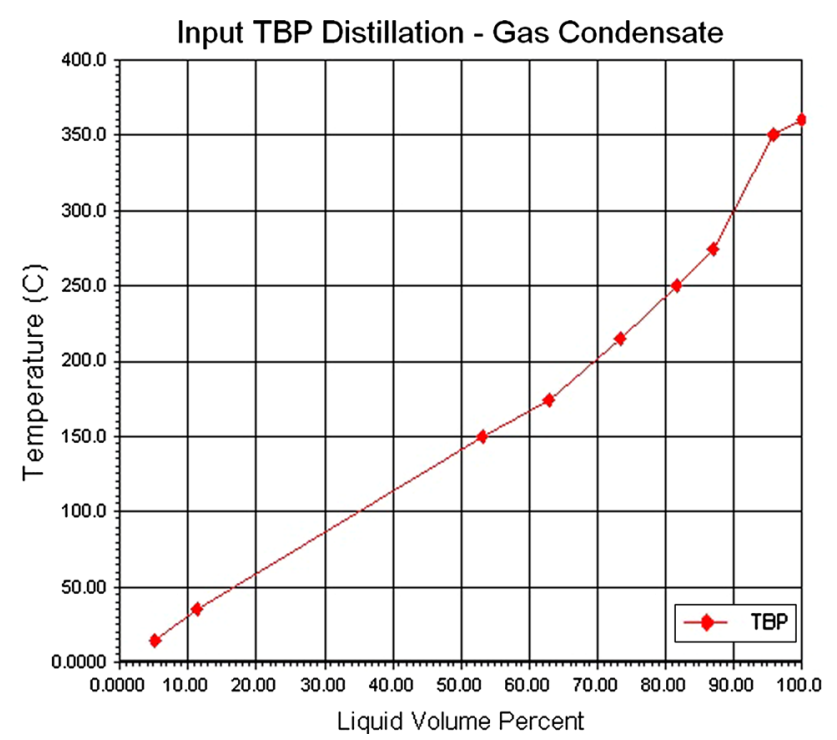

Fig. 1 The boiling point curve of gas condensate

Table 2 The non-sulfuric components of gas condensate

\begin{tabular}{ll}
$\begin{array}{l}\text { Non-sulfuric Components in Gas } \\
\text { Condensate }\end{array}$ & $\begin{array}{l}\text { Content in gas condensate, } \\
\text { wt\% }\end{array}$ \\
\hline Propane & 0.3295 \\
n-Butane & 1.7320 \\
i-Butane & 0.7798 \\
n-Pentane & 0.0212 \\
i-Pentane & 0.1602 \\
Water & 0.0080 \\
C6+ & 96.75 \\
\hline
\end{tabular}

It was assumed that the flow of DSO with volumetric rate of 293 barrels per day (the maximum daily produced rate of DSO in the South Pars refinery) was mixed with 40,000 barrels per day of gas condensate. This mixed stream was called feed and it was sent to UDHDS unit. Reducing the sulfur content of feed flow to less than $10 \mathrm{ppm}$ as sulfur, the simulated UDHDS unit could completely remove DSO. 
Table 3 The sulfuric components of gas condensate

$\overline{\text { Sulfuric components in gas condensate Content in gas condensate }}$ (as sulfur), ppm w

\begin{tabular}{lr}
\hline Methyl Mercaptan & 20 \\
Ethyl Mercaptan & 350 \\
I-Propyl Mercaptan & 250 \\
T-Butyl mercaptan & 10 \\
N-Propyl mercaptan & 100 \\
2-Butyl mercaptan & 210 \\
$i$-Butyl mercaptan & 10 \\
N-Butyl mercaptan & 100 \\
Linear High molecular weight RSH & 570 \\
Sulfides & 300 \\
Aryl-Sulfides & 75 \\
Benzothiophenes & 56 \\
Naphthenic-Benzothiophenes & 12 \\
Dibenzothiophenes & 59 \\
Sum & 2122 \\
\hline
\end{tabular}

In order to simulate the UDHDS unit plus a distillation section to treat gas condensate plus DSO stream, Aspen HYSYS software package was used. The first step in this simulation is related to definition of feed stream for the software. A new case should be generated. Then, before starting the characterization process, a property package should be selected and all the non-oil components, specifically the light ends which are pure components with low boiling points, components in the boiling point range of $\mathrm{C} 2$ to n-C5 as well as all sulfuric components had to be added. Next, Enter Basis Environment and Oil Manager Tabs should be selected, respectively, in order to define oil characterization and through this section the assay of gas condensate based on its True Boiling Point (TBP) was defined. In addition, bulk properties for the sample might also be supplied. In the cases that a distillation curve is available, bulk properties can be optional. However, bulk properties like molecular weight, mass density, Watson (UOP) $K$ Factor, and bulk viscosities can increase the accuracy of calculations in HYSYS. In this simulation, the values of molecular weight and mass density for gas condensate were 120 and $756 \mathrm{~kg} / \mathrm{m}^{3}$, respectively.

Afterwards, the oil should be installed in the flowsheet. Finally, in the main simulation environments, two streams of gas condensate and DSO could be created. A brief process description is described as follows.

\section{Process description}

Figure 2 indicates a brief Process Flow Diagram (PFD) of this process.
According to Fig. 2, a stream of gas condensate with flow rate of $200,000 \mathrm{~kg} / \mathrm{hr}$ at the ambient condition $\left(27^{\circ} \mathrm{C}\right.$ of temperature and atmospheric pressure) was mixed with $2000 \mathrm{~kg} / \mathrm{hr}$ of DSO called feed. The pressure of feed stream had to be raised to 49 bara using the feed pump. Then, a hydrogen stream called Make-up $\mathrm{H}_{2}$ stream with flow rate of $246 \mathrm{~kg} / \mathrm{hr}$ and $99.9 \mathrm{~mol} \%$ of purity was sent to a mixer using a compressor where it combined with a part of recycle hydrogen with $60 \mathrm{~mol} \%$ purity from Amine Unit. The recycle hydrogen stream with flow rate of $30838.76 \mathrm{~kg} / \mathrm{hr}$, which was the outlet stream of Amine Unite, was divided into two equal streams. One of them was used as a quench stream which should also be divided into two equal streams and injected into UDHDS Reactor from two points between beds. Another one was sent to the mixer to mix with Make-up hydrogen. In order to increase the pressure of recycle hydrogen to 47 bara, a compressor was also applied. Then, blended hydrogen was combined with feed and this stream was called combined feed.

To save energy, heat exchange occurred between the combined feed and the outlet stream of UDHDS Reactor in the UDHDS Preheater. Afterward, the hot combined feed with temperature of $264{ }^{\circ} \mathrm{C}$ entered the Furnace. The temperature of the furnace outlet stream should be kept constant at $330{ }^{\circ} \mathrm{C}$, which entered the UDHDS Reactor. This Reactor had quench streams of hydrogen between beds as reactions were exothermic and these streams could partially cool down the reactor.

UDHDS Reactor should be a trickle bed reactor. In the reactor, sulfur compounds were converted to $\mathrm{H}_{2} \mathrm{~S}$ in the presence of catalyst and hydrogen, with high pressure and temperature around 40 bara and $330{ }^{\circ} \mathrm{C}$, respectively. To simulate the reactor in HYSYS, the general reactor mode was chosen and the relevant reactions were defined based on the conversion reactor model. Some of the most important chemical reactions taking place in this process are described as follows:

$$
\begin{aligned}
& \mathrm{CH}_{3} \mathrm{SH}+\mathrm{H}_{2} \rightarrow \mathrm{CH}_{4}+\mathrm{H}_{2} \mathrm{~S} \\
& \mathrm{C}_{2} \mathrm{H}_{5} \mathrm{SH}+\mathrm{H}_{2} \rightarrow \mathrm{C}_{2} \mathrm{H}_{6}+\mathrm{H}_{2} \mathrm{~S} \\
& \mathrm{C}_{2} \mathrm{H}_{6} \mathrm{~S}_{2}+3 \mathrm{H}_{2} \rightarrow 2 \mathrm{CH}_{4}+2 \mathrm{H}_{2} \mathrm{~S} \\
& \mathrm{C}_{4} \mathrm{H}_{10} \mathrm{~S}_{2}+3 \mathrm{H}_{2} \rightarrow 2 \mathrm{C}_{2} \mathrm{H}_{6}+2 \mathrm{H}_{2} \mathrm{~S}
\end{aligned}
$$

Reactor outlet stream was cooled in UDHDS Preheater to around $150{ }^{\circ} \mathrm{C}$. Then, this stream was sent to Hot Separator. In this separator, a stream of light hydrocarbons which was rich in $\mathrm{H}_{2}\left(50 \%\right.$ mol) containing $\mathrm{H}_{2} \mathrm{~S}(1.1 \%$ mol) was removed from top of the vessel at 16.5 bara and $147{ }^{\circ} \mathrm{C}$. The pressure of this stream decreased to 16.5 bara after passing through a valve and Hot Separator. The top stream of Hot Separator after mixing with water used to wash ammonium, was cooled to $40{ }^{\circ} \mathrm{C}$ and sent to Cold 
Table 4 The components of DSO

\begin{tabular}{lll}
\hline Sulfur component in DSO & $\begin{array}{l}\text { Mass fraction, } \\
\%\end{array}$ & \begin{tabular}{l}
${ }^{\circ} \mathrm{Coiling}$ \\
\hline $\begin{array}{l}\text { Dimethyl disulfide (DMDS), } \\
\mathrm{CH}_{3} \mathrm{SSCH}_{3}\end{array}$
\end{tabular} \\
$\begin{array}{l}\text { Diethyl disulfide (DEDS), } \\
\mathrm{C}_{2} \mathrm{H}_{5} \mathrm{SSC}_{2} \mathrm{H}_{5}\end{array}$ & 50 & 110 \\
\hline
\end{tabular}

Separator. The temperature of this stream should be reduced to $40{ }^{\circ} \mathrm{C}$ in two steps. First, it was cooled to $105{ }^{\circ} \mathrm{C}$ using an Air Cooler. Then, this stream entered a Cooler in which its temperature reached $40{ }^{\circ} \mathrm{C}$. Water was utilized as a coolant in this cooler. Figure 3 shows the scheme of the reaction section of the UDHDS unit which was simulated using the Aspen HYSYS software.

Rich $\mathrm{H}_{2}$ with $4 \%$ (wt) of $\mathrm{H}_{2} \mathrm{~S}$ exiting from the top of the Cold Separator entered the Amine Treating Column. This column removed $\mathrm{H}_{2} \mathrm{~S}$ from $\mathrm{H}_{2}$ stream using a counter current amine solution stream (20 wt\% DE Amine solution), at the high pressure about 14 bara and the low temperature about $45^{\circ} \mathrm{C}$. Treated $\mathrm{H}_{2}$ with about $29 \mathrm{~mol} \mathrm{ppm} \mathrm{H}_{2} \mathrm{~S}$ exited from the top of Amine Column and then left the section. To avoid the accumulation of light hydrocarbon gases, a large proportion of this stream (99\%) returned to UDHDS unit by a compressor and the rest was sent to flare. The scheme of simulated Amine unit (Aspen HYSYS) is shown in Fig. 4.

The water stream from the boot of the Cold Separator called sour water left this system as waste. The outlet stream from the bottom of the Hot Separator including liquid hydrocarbon was combined with Cold Separator bottom stream and was fed into the Stripper for $\mathrm{H}_{2} \mathrm{~S}$ stripping. It was assumed that pressure of Stripper was around 15 bara. Having passed through the stripper condenser, the light gas stream made up of methane, ethane, $\mathrm{H}_{2}, \mathrm{H}_{2} \mathrm{O}$, and $\mathrm{H}_{2} \mathrm{~S}$ left the reflux drum of Stripper and entered the Amine plant where it was used as the fuel gas.

The bottom stream of reflux drum containing liquid hydrocarbon returned to Stripper as the reflux stream. The outlet stream from the bottom of Stripper at temperature of $249{ }^{\circ} \mathrm{C}$ should be sent to distillation section to fractionalize. The scheme of Stripper simulated using Aspen HYSYS is indicated in Fig. 5.

In the distillation section the temperature of stripper bottom stream had to be raised to $310^{\circ} \mathrm{C}$ using distillation furnace. Furthermore, the pressure of this stream should be reduced to approximately 2.7 bara (using a valve) to enter the distillation column. The scheme of distillation section is shown in Fig. 6. The high pressure steam at temperature of $350{ }^{\circ} \mathrm{C}$ and pressure of 12.8 barg was injected to the bottom of distillation column. The temperature of the top stage of distillation column was simulated to be around $94{ }^{\circ} \mathrm{C}$. Then this flow was cooled to around $74{ }^{\circ} \mathrm{C}$ using the condenser of the distillation column.

The water stream is removed from the bottom of the distillation reflux drum. Also, light gases eliminated from top of the reflux drum combined with the liquid flow removed from the bottom of reflux drum. Then, this stream after cooling using an air cooler and a cooler was sent to a separator to eliminate the remaining water. The water stream from the bottom of this separator was mixed with the water from the bottom of the distillation reflux drum. It could be saved or be sent out of this plant.

The dehydrated hydrocarbon stream leaving the separator was sent to Debutanizer column containing 10 trays in which a stream of butane from the top of this column and a stream of light naphtha from its bottom were obtained. These light products contained no sulfuric components. Figure 7 indicates the scheme of Debutanizer column.

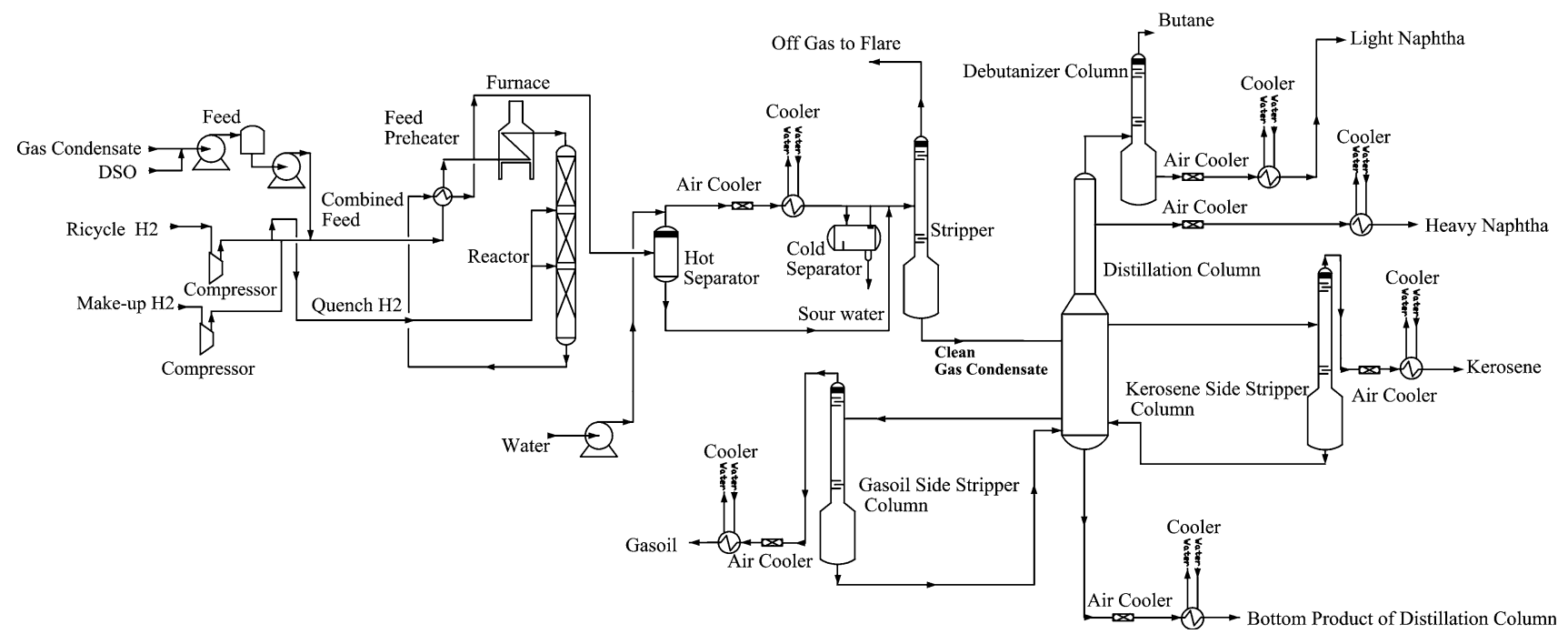

Fig. 2 The PFD of UDHDS unit plus distillation section 
The side stream drawn from the 26th tray of the distillation column was called heavy naphtha and it was sulfur free. This product should be cooled using an air cooler and a cooler to reach the ambient temperature $\left(27^{\circ} \mathrm{C}\right)$. The second side stream of the distillation column drawn from tray 28 was sent to a side stripper called kerosene side stripper. The steam at temperature of $350{ }^{\circ} \mathrm{C}$ and pressure of 13.8 bara (12.8 barg) was fed to the kerosene side stripper.

The bottom product of this column known as kerosene should be cooled using an air cooler and a cooler to reach the ambient temperature. The third side stream of the distillation column exiting from tray 29 went to the gasoil side

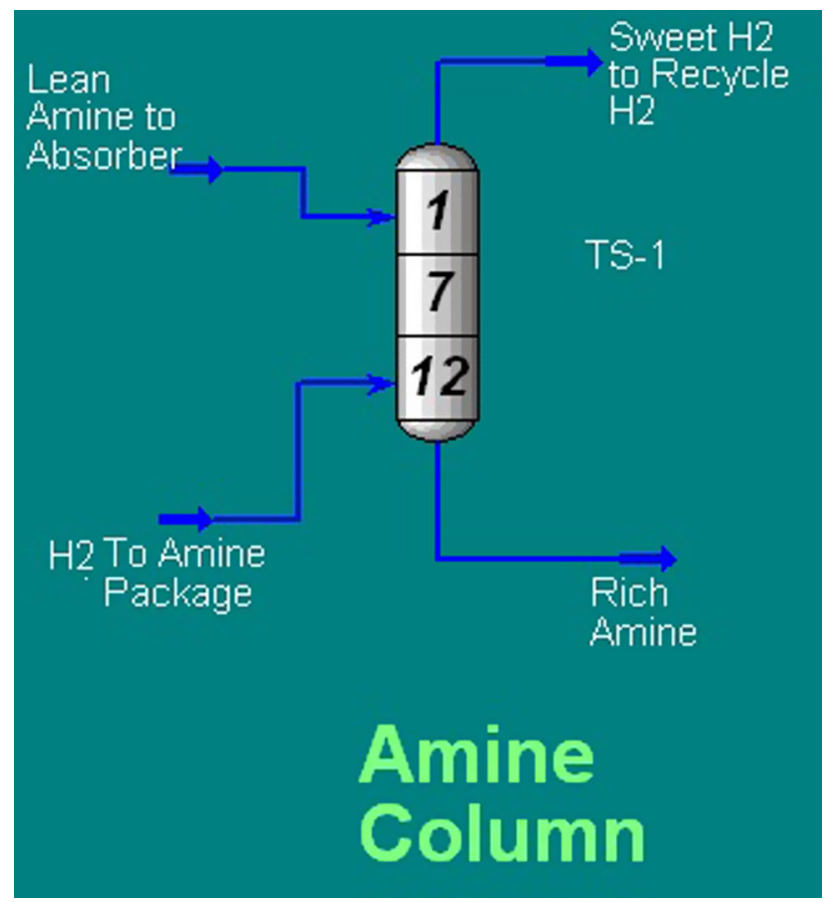

Fig. 3 The scheme of the reaction section of UDHDS unit stripper. The steam at temperature of $350{ }^{\circ} \mathrm{C}$ and pressure of 13.8 bara entered this column.

The bottom stream of this column called gasoil should be cooled using an air cooler and a cooler to reach the ambient temperature. Finally, the small amount of hydrocarbons called Bottom Product of Distillation column left the bottom of the distillation column which had to be cooled to reach the ambient temperature using an air cooler and a cooler. These clean products of butane, light naphtha, heavy naphtha, kerosene, gasoil, and condensate can be stored in the storage tanks.

\section{Results and discussion}

Aspen HYSYS software was used to simulate the UDHDS unit for a mixture of gas condensate and DSO. It was shown that this process involved three general sections: reaction, stripping, and distillation. The tray stripper was used to remove hydrogen sulfide from gas condensate. Based on the simulation result, Stripper required 20 stages to remove the significant amount of $\mathrm{H}_{2} \mathrm{~S}$ from the gas condensate. Moreover, the feed stream entered the stripper from tray 5.

The bottom product of Stripper known as the clean gas condensate included no $\mathrm{H}_{2} \mathrm{~S}$ and its total sulfur content was simulated to be less than $10 \mathrm{ppmw}$ as sulfur. Afterward, to obtain different fractions, this bottom product was sent to a distillation column involving 30 stages. The gas condensate is composed of many components with boiling points covering a great range of temperatures. Each product has a boiling range having an initial boiling point (I.B.P.) and a final boiling point (F.B.P.). There are different ranges of boiling points for different cuts indicated in the literature. Some of them are shown in Table 5. In the present study, the boiling point ranges of different cuts were defined based

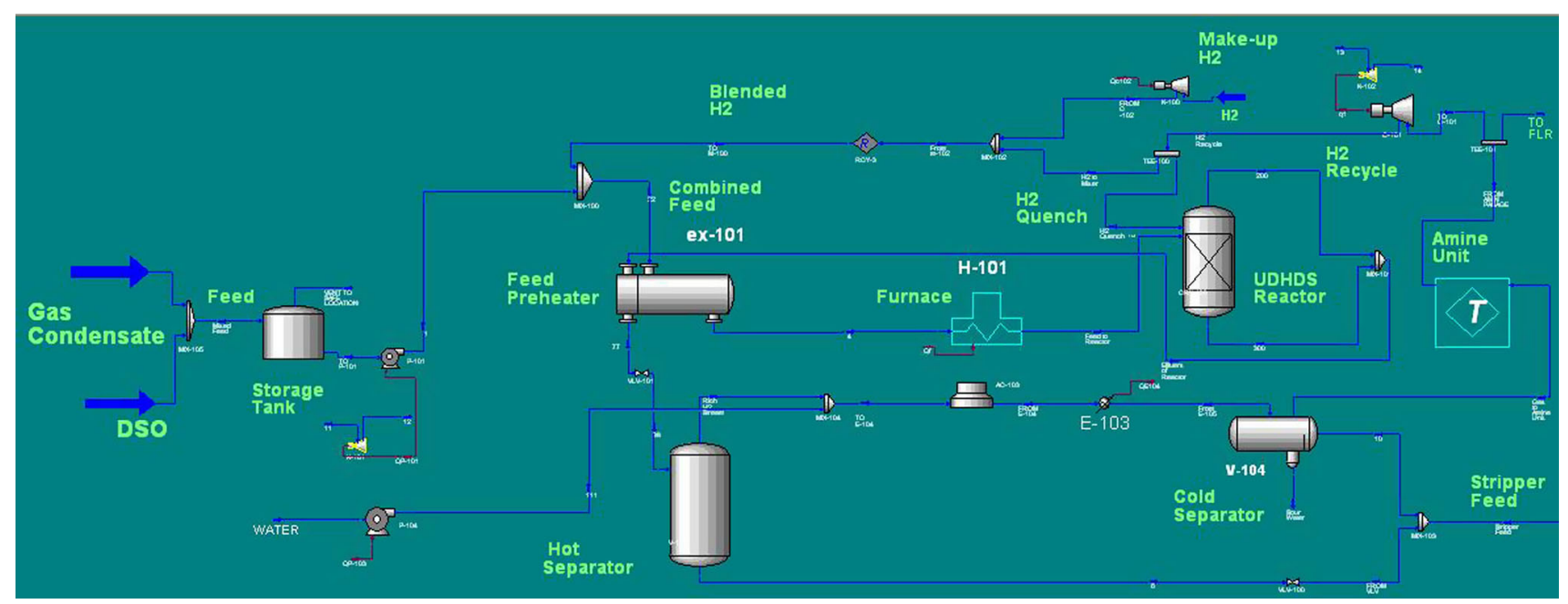

Fig. 4 The scheme of the Amine unit 
on the data elicited from the Website of Chevron Company [14], which is shown in the third column of Table 5.

In order to recognize each cut, the range of its boiling points should be considered and compared. According to the data of Table 5 and the range of boiling points of gas condensate listed in Table 1, the volumetric rate of each cut could be estimated and used as initial values to simulate this unit using the Aspen HYSYS software. As a result, it was assumed that the estimated volumetric rates of light naphtha, heavy naphtha, kerosene, and gasoil were approximately $12,40,18$, and $19 \%$ (volumetric percent) of gas condensate $(40,000$ barrel per day), respectively.

The simulation results revealed that five different cuts were fractionized from the clean gas condensate using distillation section. The sulfur content of each cut was less than $30 \mathrm{ppmw}$ as sulfur. The simulation results based on the mass balance are summarized in Table 6. Regarding

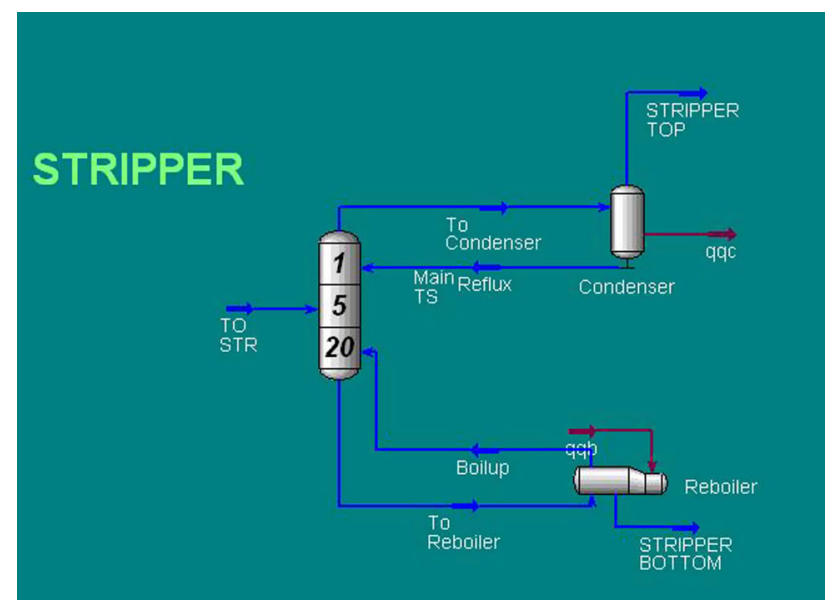

Fig. 5 The scheme of stripping section
Table 6, it can be concluded that butane, light naphtha, and heavy naphtha streams were sulfur free. However, kerosene and gasoil products contained 11 and 27 ppmw as sulfur, respectively. Furthermore, the bottom product of distillation column involved approximately $29 \mathrm{ppm}$ as sulfur.

To efficiently understand this process, some of the key performance indicators of UDHDS Process were summarized in Table $7 . \mathrm{H}_{2}$ consumption is considered as one of the key performance indicators of this process which was defined as the ratio of the volumetric rate of required hydrogen (at normal condition) to the volumetric rate of feed. It should be taken into account that $\mathrm{H}_{2}$ consumption was evaluated based on the rate of hydrogen required to react with all the sulfuric components of feed and remove them. To calculate the yield of liquid product on feed, the mass flow rate of the bottom stream of Stripper called clean gas condensate was divided by the mass flow rate of feed (a combination of gas condensate and DSO).

\section{UDHDS process path forward}

Using the simulated UDHDS unit plus distillation section, the South Pars refinery would be able to treat 400,00 barrel per day of gas condensate and remove about 300 barrels per day of DSO. Major modification envisaged includes the optimization of suggested UDHDS process in this study.

Varying different operation conditions and process variables like temperatures, the number of stages of stripper and distillation columns, to name but a few, one can optimize this process to obtain the highest performance with the least cost. Some mathematical methods like Response Surface Methodology (RSM) and Artificial Neural Network

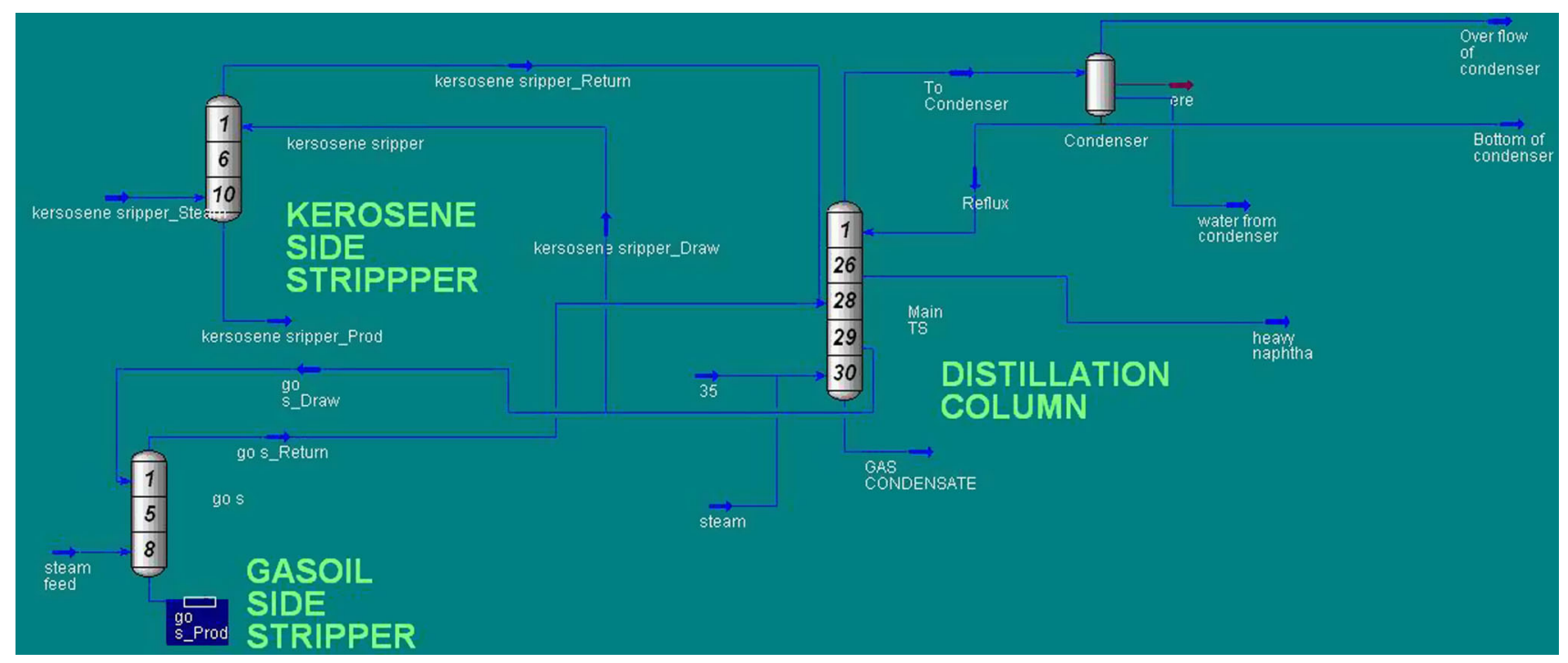

Fig. 6 The scheme of distillation section 


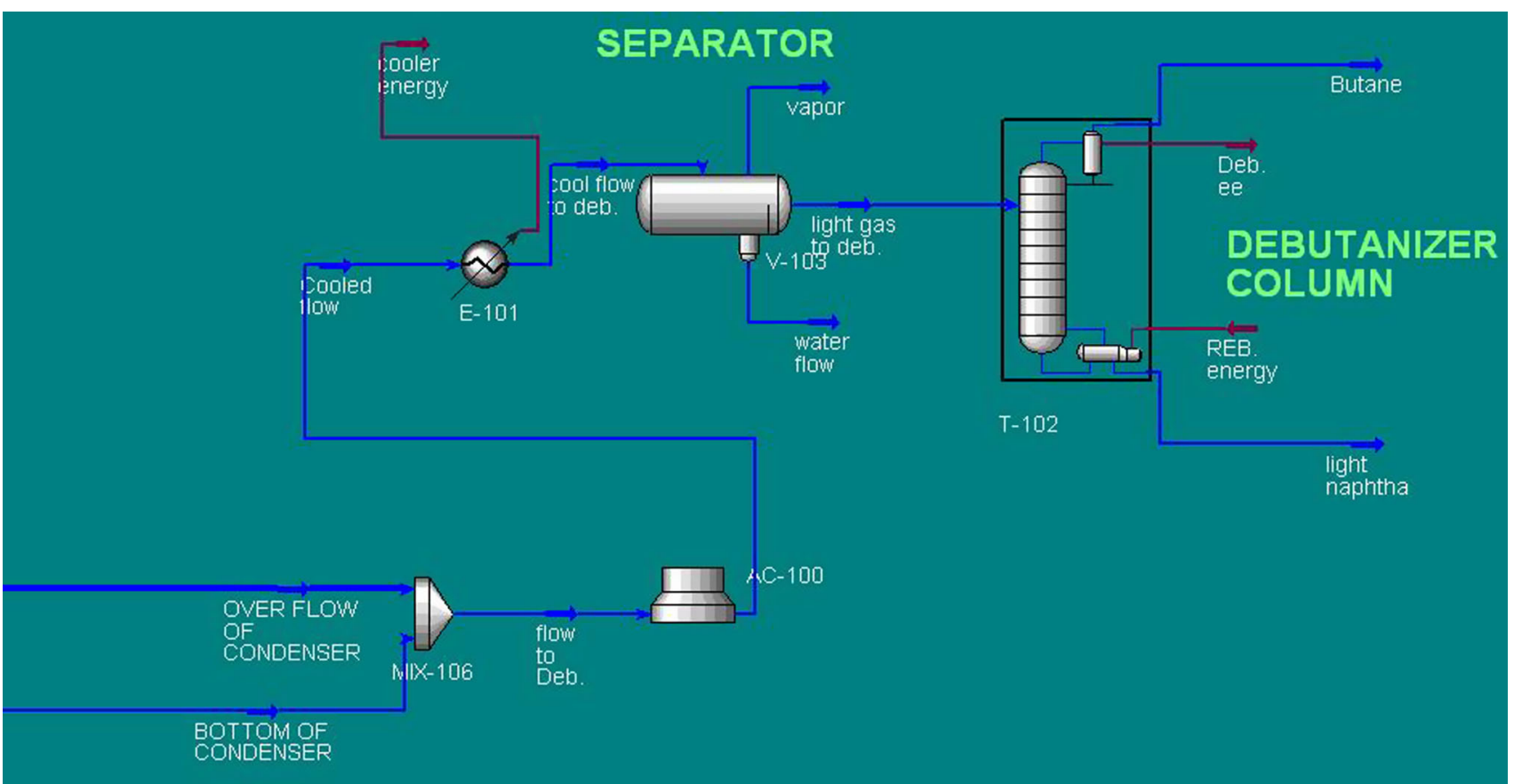

Fig. 7 The scheme of Debutanizer column

Table 5 The boiling point ranges of petroleum cuts in the literature

\begin{tabular}{|c|c|c|c|}
\hline \multirow[t]{2}{*}{ Petroleum cuts } & \multicolumn{3}{|c|}{$\begin{array}{l}\text { Boiling point ranges, }{ }^{\circ} \mathrm{C} \\
\text { Reported in the literature }\end{array}$} \\
\hline & {$[13]$} & {$[14]$} & {$[15]$} \\
\hline LPG & Up to 30 & - & - \\
\hline Light Naphtha & $30-100$ & $10-80$ & $39-85$ \\
\hline Medium Naphtha & $100-150$ & $80-150$ & $85-200$ \\
\hline Heavy Naphtha & & $150-200$ & \\
\hline Kerosene & $150-250$ & $200-260$ & $170-270$ \\
\hline Light Gasoil & $250-350$ & $260-340$ & $180-340$ \\
\hline Heavy Gasoil & $350-450$ & & \\
\hline Residue & Over 450 & Over 340 & - \\
\hline
\end{tabular}

(ANN) can be used as efficient tools to optimize this process, in the future studies. In the cases that the lower amount of sulfur content in gas condensate will be required, some essential modification can be carried out as follows:

A larger reactor

Reducing LSHV

The larger amount of $\mathrm{H}_{2} / \mathrm{Oil}$ ratio

Stripper with more stages

\section{Conclusion}

The present study was based on the simulation of an industrial process in which the simulation can be used as a tool to predict the quality of products of this process. In order to obtain the ultra-low sulfur gas condensate and remove DSO stream from the South Pars refinery, a UDHDS unit was simulated. Not only could the simulated UDHDS unit reduce the sulfur content of gas condensate to less than $10 \mathrm{ppmw}$ as sulfur, but it could also remove DSO which was considered as a serious environmental issue. Subsequently, to obtain the ultra-low sulfur cuts from the clean gas condensate, a distillation section involving two side strippers and one debutanizer column was simulated. The simulation of UDHDS unit and distillation section was conducted using the Aspen HYSYS software package. The simulation results showed that five cuts involving butane, light naphtha, heavy naphtha, kerosene, and gasoil could be fractionized from gas condensate using a distillation unit. The sulfur content of 
Table 6 Mass balance

\begin{tabular}{|c|c|c|c|c|c|c|c|c|c|c|c|c|c|c|}
\hline Stream Description & $\begin{array}{l}\text { Gas } \\
\text { Condens }\end{array}$ & sate ${ }^{\text {DSO }}$ & Feed & $\begin{array}{l}\text { Make- } \\
\mathrm{Up} \mathrm{H}_{2}\end{array}$ & $\begin{array}{l}\text { Recycl } \\
\mathrm{H}_{2}\end{array}$ & $\begin{array}{ll}\mathrm{Qu} \\
\\
\mathrm{H}_{2}\end{array}$ & nch & $\begin{array}{l}\text { Blenc } \\
\mathrm{H}_{2}\end{array}$ & ded & $\begin{array}{l}\text { Comb } \\
\text { Feed }\end{array}$ & $\begin{array}{ll}\text { pined } & \mathrm{Sc} \\
& \mathrm{O}\end{array}$ & $\begin{array}{l}\text { Sour Water to } \\
\text { JSBL }\end{array}$ & $\begin{array}{l}\text { Strippe } \\
\text { to FLF }\end{array}$ & $\begin{array}{l}\text { er Off-Gas } \\
\mathrm{R}\end{array}$ \\
\hline Flow rate $(\mathrm{kg} / \mathrm{hr})$ & 200,000 & 2000 & $202,000 \quad 2$ & 246 & 30,780 & & 390 & 15,63 & & 217,63 & & 3067 & 3759 & \\
\hline Phase & $\mathrm{L}$ & $\mathrm{L}$ & $\mathrm{L}$ & $\mathrm{G}$ & G & G & & G & & L-G & $\mathrm{L}$ & 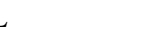 & $\mathrm{G}$ & \\
\hline Pressure (barg) & 0 & 5.4 & 0 & 46.5 & 46 & 46 & & 46 & & 46 & & 4.2 & 14 & \\
\hline Temperature $\left({ }^{\circ} \mathrm{C}\right)$ & 27 & 50 & 27.17 & 198 & 172 & 17 & & 173 & & 50 & & 10 & 42.5 & \\
\hline Density $\left(\mathrm{kg} / \mathrm{m}^{3}\right)$ & 761 & 999 & 754 & 2.58 & 13.71 & 13 & & 12.85 & & 122 & & 96.4 & 21.1 & \\
\hline $\begin{array}{l}\text { Sulfur Component (as } \\
\text { S), wt } \%\end{array}$ & 0.21 & 60 & 1.2 & 0 & 0 & 0 & & 0 & & 0.451 & 0 & ) & 0 & \\
\hline Hydrogen, wt $\%$ & 0 & 0 & 0 & 99.9 & 11.1 & 11 & & 12.4 & & 0.8 & 0 & ) & 0.8 & \\
\hline $\mathrm{H}_{2} \mathrm{~S}, \mathrm{wt} \%$ & 0 & 0 & 0 & 0 & 0.009 & 0.0 & & 0.009 & & 0.0006 & & .01 & 6 & \\
\hline $\mathrm{H}_{2} \mathrm{O}, \mathrm{wt} \%$ & 0.01 & 0 & 0.01 & 0 & 1.1 & 1.1 & & 1.1 & & 0.09 & & 9.09 & 0.5 & \\
\hline Light Gas, wt $\%$ & 3 & 0 & 2.9 & 0.1 & 88.79 & 88 & & 86.49 & & 9.11 & 0 & ) & 92 & \\
\hline Condensate, wt $\%$ & 97 & 0 & 96.1 & 0 & 0 & 0 & & 0 & & 89.1 & 0 & ) & 0 & \\
\hline $\begin{array}{l}\text { Dimethyldisulfide, } \\
\text { wt } \%\end{array}$ & 0 & 50 & 0.5 & 0 & 0 & 0 & & 0 & & 0.46 & 0 & ) & 0 & \\
\hline Diethyldisulfide, wt\% & 0 & 50 & 0.5 & 0 & 0 & 0 & & 0 & & 0.46 & 0 & ) & 0 & \\
\hline Stream Description & & $\begin{array}{l}\text { Stripper } \\
\text { Bottom }\end{array}$ & $\begin{array}{l}\text { Feed to } \\
\text { distillation } \\
\text { column }\end{array}$ & $\begin{array}{ll}\text { to } \\
\text { in }\end{array}$ & nizer & Butane & & htha & $\begin{array}{l}\text { Wate } \\
\text { to OS }\end{array}$ & SBL & $\begin{array}{l}\text { Heavy } \\
\text { Naphtha }\end{array}$ & Kerosene & Gasoil & $\begin{array}{l}\text { Bottom } \\
\text { product of } \\
\text { distillation } \\
\text { column }\end{array}$ \\
\hline Flow rate $(\mathrm{kg} / \mathrm{hr})$ & & 191,900 & 191,900 & 29,910 & & 3441 & 26 & & 4915 & & 83,520 & 40,890 & 35,000 & 3040 \\
\hline Phase & & $\mathrm{L}$ & $\mathrm{G}$ & $\mathrm{L}$ & & G & $\mathrm{L}$ & & $\mathrm{L}$ & & $\mathrm{L}$ & $\mathrm{L}$ & $\mathrm{L}$ & $\mathrm{L}$ \\
\hline Pressure (barg) & & 15 & 1.7 & 1 & & 0.8 & 1.8 & & 1 & & 1.5 & 1.5 & 1.5 & 1.5 \\
\hline Temperature $\left({ }^{\circ} \mathrm{C}\right)$ & & 249 & 310 & 50 & & 14.25 & 25 & & 25 & & 25 & 25 & 25 & 25 \\
\hline Density $\left(\mathrm{kg} / \mathrm{m}^{3}\right)$ & & 531.3 & 6.8 & 650 & & 4.7 & 690 & & 1007 & & 742 & 787 & 832 & 821 \\
\hline Sulfur Component (as S & S), wt $\%$ & 0.0007 & 0.0007 & 0 & & 0 & 0 & & 0 & & 0 & 0.0011 & 0.0027 & 0.003 \\
\hline Hydrogen, wt $\%$ & & 0 & 0 & 0 & & 0 & 0 & & 0 & & 0 & 0 & 0 & 0 \\
\hline $\mathrm{H}_{2} \mathrm{~S}, \mathrm{wt} \%$ & & 0 & 0 & 0 & & 0 & 0 & & 0 & & 0 & 0 & 0 & 0 \\
\hline $\mathrm{H}_{2} \mathrm{O}, \mathrm{wt} \%$ & & 0 & 0 & 0.03 & & 0.2 & 0 & & 100 & & 0.018 & 0.1 & 0.075 & 0.0082 \\
\hline Light Gas, wt $\%$ & & 0.5 & 0.5 & 12 & & 99.8 & 1.2 & & 0 & & 0.1 & 0 & 0 & 0.033 \\
\hline Condensate, wt $\%$ & & 99.44 & 99.44 & 87.97 & & 0 & 98. & & 0 & & 88.54 & 99.9 & 92.2 & 95.6 \\
\hline Dimethyl disulfide, wt $\%$ & & 0 & 0 & 0 & & 0 & 0 & & 0 & & 0 & 0 & 0 & 0 \\
\hline Diethyl disulfide, wt\% & & 0 & 0 & 0 & & 0 & 0 & & 0 & & 0 & 0 & 0 & 0 \\
\hline
\end{tabular}

Table 7 Key performance indicators of UDHDS process

\begin{tabular}{ll}
\hline $\mathrm{H}_{2}$ Consumption, $\mathrm{Nm}^{3} / \mathrm{m}^{3}$ of feed & 13 \\
Desulfurization, $\%$ & 99.98 \\
Yield of liquid product on feed, \% & 95 \\
\hline
\end{tabular}

each product was less than $30 \mathrm{ppmw}$ as sulfur. This study can be used as a base to establish a UDHDS unit plus distillation section in this refinery as this process is capable of solving environmental problems and turning profit. In addition, it can be considered as the first step for further studies in order to optimize this process.

Open Access This article is distributed under the terms of the Creative Commons Attribution 4.0 International License (http:// creativecommons.org/licenses/by/4.0/), which permits unrestricted use, distribution, and reproduction in any medium, provided you give appropriate credit to the original author(s) and the source, provide a link to the Creative Commons license, and indicate if changes were made.

\section{References}

1. Manning FS, Thompson RE (1991). Oilfield Processing of Petroleum (Volume One:Natural Gas). Pennwell Books. ISBN 0-87814-343-2

2. Medde $\mathrm{M}$ The Ph.D. thesis in ingegneria industriale università degli studi di cagliari, "experimental analysis and modelling of gasoil hydrotreatment process"

3. Sadighi S, Seif Mohaddecy SR, Ghabouli O, Bahmani M (2009) Revamp of naphtha hydrotreating process in an iranian refinery. Pet Coal J 51(1):45-50 
4. Gheni SA, Jada'a WA (2012) Inhibitory study for joint reactions of hydrodesulphurization and hydrodenitrogenation during hydrotreating of vacuum gas oil. In: Proceedings of the world congress on engineering and computer science 2012, vol II. WCECS, San Francisco, USA

5. Kabe T, Ishihara A, Qian W (1999) Hydrodesulphurization and Hydrodenitrogenation. Kodansha Ltd., Tokyo, WILEY-VCH Verlag GmbH, Weinheim

6. Babich IV, Moulijn JA (2003) Science and technology of novel processes for deep desulfurization of oil refinery streams. Fuel J 82(6):607-740

7. Rang H, Kann J, Oja V (2006) Advances in desulfurization research. Oil Shale 23(2):164-176

8. Bilal S, Mohammed Dabo IA, Mujahid AU, Kasim SA, Nuhu M, Mohammed A, Abubakar HM, Yahaya UB, Habib A, Abubakar B, Aminu YZ (2013) Simulation of hydrodesulphurization (HDS) unit of Kaduna Refining and Petrochemical Company Limited. Chem Process Eng Res 13:29-35

9. Jiménez F, Kafarov V, Nuñez M (2006) Computer-aided modeling for hydrodesulfurization, hydrodenitrogenation and hydrodearomatization simultaneous reactions in a hydrotreating industrial process. Comput Aided Chem Eng 21:651-657

10. Arce-Medina E, Paz-Paredesb JI (2009) Artificial neural network modeling techniques applied to the hydrodesulfurization process. Math Comput Modelling J 49:207-214

11. Technical Recommendation Study Report for HQCEC Company

12. Morgott D, Lewis C, Bootman J, Banton M (2014) Disulfide oil hazard assessment using categorical analysis and a mode of action determination. Int J Toxicol 33:181S-198S. doi:10.1177/ 1091581813504227

13. Al-Assady Q (2009) Characterization of petroleum fractions. Iraqi J Mech Mater Eng 9(2):223-238

14. Refinery Feedstocks and Products- Properties and Specifications, Colorado School of Mines, Page: 21, http://inside.mines.edu/ $\sim$ jjechura/Refining/02_Feedstocks_\&_Products.pdf

15. Oil Refinery Processes page: 40, http://www.uma.ac.ir/files/site1/ m_ghorbanpour_6ffe535/refinery_3.pdf 